\title{
17: 77649395-77629503
}

National Cancer Institute

\section{Source}

National Cancer Institute. 17: 77649395-77629503. NCI Thesaurus. Code C42247.

Physical location of FASN_Gene 